\title{
Original article \\ Determination of feedback in judo by means of T-patterns
}

\author{
Iván Prieto Lage \\ Alfonso Gutiérrez-Santiago \\ University of Vigo, Spain \\ Miguel Ángel Prieto Lage \\ Institute of Marine Investigation at Vigo, Spain
}

\begin{abstract}
The aim of this research was to propose methodological changes in the teaching-learning process of the judo technique Deashi-harai, pointing out the most frequent technical errors committed during its performance and also its action sequences. We carried out an observational study with the participation of fifty novice judokas at the University of Vigo. We recorded them while performing the Deashi-harai technique after a previous training of four months. Data obtained were evaluated using descriptive statistics and T-patterns analysis. Thus, we indentified: a) some typical inaccuracies during the technique execution and b) a number of chained errors affecting the imbalance of the body, the position of the right foot, the sweeping action and the action of the arms. These findings allowed us to suggest some motor tasks to correct the identified inaccuracies, the sequential actions to ensure the success of the execution and several recommendations for the proper use of the feedback.
\end{abstract}

Keywords: feedback, observation, teaching, martial arts

Resumo - "Determinação de feedback no judô por meio de T-patterns." O objetivo de esta investigação baseia-se na proposta de mudanças metodológicas no ensino/aprendizagem da técnica de judo Deashi-harai, assinalando os erros técnicos mais comuns durante a sua execução, assim como as suas sequências. Realizou-se um estudo observacional, onde participaram 50 estudantes da Universidade de Vigo sem conhecimentos prévios de Judô, foram filmados executando a técnica em estudo depois de uma formação prévia de quatro meses. Os resultados obtidos foram avaliados através de estatística descritiva e análise de T-patterns. Identificamos: a) uma diversidade de defeitos na execução da técnica; b) umas sequências de erros em cadeia que afetam consideravelmente o desequilíbrio, a posição do pé direito, a ação de varrimento e a ação dos braços. Estes resultados permitem-nos propor tarefas motrizes baseadas nos erros detetados, em sequências de movimentos que garantam o êxito na projeção e recomendações sobre a utilização do feedback.

Palavras-chave: retroalimentação, observação, ensino, artes marciais

Resumen-“Determinación del feedback en el judo a través de T-patterns." El objetivo de esta investigación es proponer cambios metodológicos en el proceso de enseñanza aprendizaje de la técnica de judo Deashi-harai, indicando los errores técnicos más comunes durante su ejecución, así como sus secuencias. Hemos realizado un estudio observacional en el que participaron 50 estudiantes de la Universidad de Vigo sin conocimiento previo de Judo, que fueron filmadas ejecutando la técnica de estudio después de un entrenamiento previo de cuatro meses. Los resultados se analizaron utilizando estadística descriptiva y análisis de T-patterns. Se ha identificado: a) una variedad de errores en la ejecución b) una secuencia de cadena de errores que afectan significativamente el desequilibrio, la posición del pie derecho, acción de barrido y la acción del brazo. Estos resultados nos permiten proponer tareas motrices basadas en los errores detectados, secuencias de movimientos que aseguran el éxito en la proyección, así como recomendaciones sobre el uso del feedback.

Palabras clave: retroalimentación, observación, enseñanza, artes marciales

\section{Introduction}

The feedback given by the trainees (Hodges \& Franks, 2002) and the use of an appropriate technique (Bandura, 1977; McCullagh, 1986; Zubiaur, 2005) are factors that significantly contribute to the teaching-learning process in both sport and physical education
(Pereira, Mesquita, Graça \& Moreno, 2010; Zabala, Sánchez -Muñoz \& Mateo, 2009). This requires a detailed knowledge of the key factors necessary to perform a motor task and knowledge of the most common errors and their sequences. This would allow us to set up some precise task-oriented feedback based on the fundamental aspects of the performance of a movement. 
Coaches usually provide feedback, based on their personal and professional experience, which can sometimes lead to mistakes during a student's learning of a judo technique. Therefore, the characteristic technical errors committed during this process are key factors in establishing suitable feedback that would facilitate the work of experts (Zubiaur, 1998).

The ability of an observational methodology to detect behaviors that occur in a sequential and temporal basis (Bakeman \& Quera, 2011) has inspired the creation of techniques that analyze such behavior (Magnusson, 2005). Among these analytical techniques, the THEME software is one of the most frequently used (Magnusson, 1996), although not the only one. The temporal pattern or T-pattern detected allows the observer to detect a motor behavior pattern that otherwise would remain unnoticed even for an experienced person. Currently, these computer tools are commonly used by the scientific community, and have had demonstrated their effectiveness in different sports (Borrie, Jonsson, \& Magnusson, 2002; Camerino, Chaverri, Anguera, \& Jonsson, 2012). They brought a substantial progress in both methodological and disciplinary aspects (Gutiérrez-Santiago, Cancela, Zubiaur, \& Ayán, 2012; Gutiérrez-Santiago, Prieto, Ayán, \& Cancela, 2013). In this regard, applying observational methodology helps to solve the problems mentioned above and to optimize feedback (Reo \& Mercer, 2004; Tzetzis, Votsis \& Kourtessis, 2008).

The purpose of this research was to determine, through observational methodology, the technical errors and their sequences during the execution of the Deashi-harai judo technique. The study also intends to illustrate the contribution of the T-patterns application (Magnusson, 1996, 2000) in the field of sports and, in particular, of judo.

\section{Methods}

In this study, we used an observational methodology (Anguera \& Jonsson, 2003) that provided us with the rigor and flexibility required for studying the behavioral episodes emerging naturally when teaching and learning judo. Based on Heineman (2003), we carried out a systematic, open and non-participating observation.

\section{Design}

The observational design (Anguera-Argilaga, Blanco-Villaseñor, Hernández-Mendo, \& Losada-López, 2011) was nomothetic (several participants performing the same technique, in this case Deashi-harai), monitoring (a technical procedure carried out during five academic years), and multidimensional (different dimensions of the observation instrument). According to this observational design, nomothetic/monitoring/multidimensional (N/N/M), we made some decisions concerning the participants, the observation, the recording instruments and the analysis procedure.

\section{Participants}

Novice students were filmed on video (with their written authorization for the research purposes) after a previous training of four months while taking part in a judo course at the University of Vigo
( $n=50 ; 25$ men and 25 women). At the beginning of the study, their

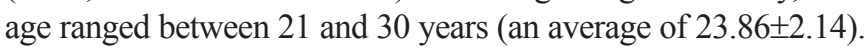
Data collection took five academic years (2003 to 2008).

\section{The observation instrument}

The observation instrument developed for this study was called SOBJUDO-DAH (see Table 1). This instrument included, as one of the criteria, to detect technical errors during the performance of the judo technique. The methodological model used for the teaching-learning process of both performances and observations was based on the recommendations from the Kodokan school (Kodokan, n.d).

The SOBJUDO-DAH fits the observational design herein presented, being multidimensional in nature. Each of the dimensions gives rise to a system of categories that meets the conditions of exhaustiveness and mutual exclusivity (EME):

\section{Procedure}

Data collection was performed by recording the student's movement from two different angles with two digital cameras (JVC GZ-MG21E). The technical execution of Deashi-harai was filmed after the ordinary teaching-learning period (four months with three hours of practice per week) at the University of Vigo. The filmed material was obtained by recording each participant performing the judo technique with no opponent, and in a static position (technical). The recordings were edited with the software Pinnacle Studio v.12 for further analysis. Subsequently, in order to perform systematic observational analysis, we utilized Match Vision Studio Premium v.3.0. (Castellano, Perea, Alday \& Hernández, 2008). This software is a multimedia interactive program used to simultaneously view and register the filmed material in a computer. All the recorded actions were exported to Excel files.

The outcome quality control of the recorded data, performed by two observers, was assessed via Cohen's Kappa (Cohen, 1968 ) coefficient $(k)$, in order to ensure agreement between the observers $(k>0.80)$. Using GSEQ software (Bakeman \& Quera, 1992, 2001), we obtained the Cohen's Kappa value for this study $(k=0.83)$. Once this criterion was met, an initial descriptive analysis of frequencies and percentages of occurrence of technical errors was conducted.

Excel file data was exported to the software THEME (Magnusson, 2000, 2005) in order to determine the temporal pattern. A temporal pattern is essentially a combination of events that occur in the same order with the time intervals between consecutive pattern components remaining relatively unchanged. The null hypothesis was that each component was independently and randomly distributed over time. The T-pattern was obtained by means of the algorithm incorporated within THEME v.5, which helps to reveal hidden structures and unobservable aspects in the judo sport technique. The application of this software proved to be highly effective for this study, for individual and combat sports (Fernández, Camerino, Anguera \& Jonsson, 2009; Gutiérrez-Santiago, Cancela, Zubiaur \& Ayán, 2012; GutiérrezSantiago, Prieto, Camerino \& Anguera, 2011). 
Table 1. SOBJUDO-DAH observational instrument.

\begin{tabular}{|c|c|c|}
\hline CRITERION & CODE & DESCRIPTION \\
\hline Grip & AGR & $\begin{array}{l}\text { The Tori (the judoka that performs the action) uses his left hand to grip the Uke's (the judoka that receives the action) } \\
\text { midway up the forearm. }\end{array}$ \\
\hline Off-balance & NOB & $\begin{array}{l}\text { The Tori does not put the Uke off balance in the first stage of the technique. His arms keep the initial grip, accom- } \\
\text { panying only the action instead off pushing firmly into pull motion movement generated from the rotation of the hips. }\end{array}$ \\
\hline $\begin{array}{l}\text { Right-foot } \\
\text { position }\end{array}$ & IRFP & $\begin{array}{l}\text { During the Tsukuri (middle stage of the technique), the Tori places his right foot (the none sweeping one) opposite } \\
\text { of the Uke's right foot }(\sim 20 \mathrm{~cm}) \text {. }\end{array}$ \\
\hline \multirow[t]{4}{*}{$\begin{array}{l}\text { Sweeping } \\
\text { action }\end{array}$} & SWPS & $\begin{array}{l}\text { The Tori sweeps the Uke's body at any of the following places: the advancing leg, both feet, at the middle part of the } \\
\text { calf right leg, above the malleolus of the right leg or no contact is made with any part of the Uke's body. }\end{array}$ \\
\hline & SWMC & $\begin{array}{l}\text { The Tori makes an inappropriate mechanical sweep action for one or more of the following reasons: flexes the knee } \\
\text { joint, sweeps with the inside part of his tibia, sweeps with the internal part of the calf of the right leg or sweeps with } \\
\text { the inside part of his ankle. }\end{array}$ \\
\hline & SWMV & $\begin{array}{l}\text { The sweeping action made by the Tori should hit the Uke's right foot lower than the ankle, but above the floor }(\sim \text { at } \\
10 \mathrm{~cm}) \text { with the Tori's foot sole, when the Uke's swept leg is still in the air and no weight is loaded on it. }\end{array}$ \\
\hline & SWTM & $\begin{array}{l}\text { Timing is a key aspect in the performance of the technique. The sweep action of the Uke's leg must be done just } \\
\text { before the Uke loads the weight on it. Too soon and he may be able to bring it back up. Too late and the Uke's weight } \\
\text { is on it and the Tori would not be able to finish the sweep. }\end{array}$ \\
\hline \multirow[t]{2}{*}{ Arm action } & $\mathrm{RAB}$ & $\begin{array}{l}\text { In the last part of the execution, the Tori, with his left arm, does not pull down the Uke's right arm in the sweep } \\
\text { direction, and also with his right arm does not pull right up the Uke's left arm displacing his body slightly back. }\end{array}$ \\
\hline & $\mathrm{LAB}$ & $\begin{array}{l}\text { At last part of the execution, the Tori's left arm does not apply enough traction or, if it does, the direction of arm is } \\
\text { incorrect (generally straight down forward or against the sweep). }\end{array}$ \\
\hline \multirow[t]{2}{*}{ Throw stage } & TB & During the final stage of the technique, the Tori performs a trunk flexion, around $70^{\circ} / 90^{\circ}$ \\
\hline & $\mathrm{CR}$ & During the sweeping action, the Tori's left leg is placed in front of his right leg. \\
\hline \multirow{3}{*}{$\begin{array}{l}\text { Control } \\
\text { stage }\end{array}$} & FACC & During the guiding stage, the Tori uses his right arm to accompany the Uke's fall to the floor. \\
\hline & FNC & $\begin{array}{l}\text { During the final stage of the technique, the Tori performs no action with his left hand and, therefore, fails to control } \\
\text { the fall of his adversary's body. }\end{array}$ \\
\hline & KTB & $\begin{array}{l}\text { During the final stage of the technique, the Tori performs a trunk flexion, around } 70^{\circ} \text { keeping it after the end of the } \\
\text { execution. }\end{array}$ \\
\hline \multirow[t]{2}{*}{ Rebalancing } & RRF & After performing the throw, the Tori loses his balance. In order to regain it, he steadies himself with his right foot. \\
\hline & RLF & Upon completion of the technique, the Tori loses his balance which he regains by steadying himself with his left foot. \\
\hline Globality & SLEX & The throw is executed slowly and without any continuity. \\
\hline
\end{tabular}

\section{Statistical analysis}

The frequency of occurrence of different errors made when performing the Deashi-harai judo throw was determined by descriptive analysis using SPSS 15.The results are shown in Table 2. An analysis of the temporal patterns of observed errors was also conducted using THEME in order to identify the most significant sequence of errors. The qualitative analysis of data was performed calculating the concordance of the observers, using the Cohen's Kappa (Cohen, 1968) using GSEQ (Generalized Sequential Querier) software.

\section{Results}

In Table 2 a descriptive analysis of the errors noted in the study group $(n=50)$ is presented. The most common errors are those related to initial imbalance (NOB) including improper position of the right foot (IRFP), the incorrect performance of the sweep (SWMC and SWMV) and the action of the arms (RAB and LAB).

\section{Detection of temporal patterns}

The T-patterns (trajectory patterns) analysis showed a number of important links related to the sequence of found errors. Figures 1 and 2 show the sequence of detected errors. The left quadrant represents the relationship between the technical errors of the different categories (see observational instrument of SOBJUDO-DAH). It must be read as a tree diagram from top to bottom. The right quadrant shows the frequency of appearance of relationships by using the lines that go from the top to the bottom.

The sequential errors of the Deashi-harai judo-technique (see Figure 1) showed that a Tori performs incorrectly the action of imbalance on his opponent (NOB) and then approaches his right foot towards the same foot of the opponent (IRFP). 
Table 2. Frequency and percentage of occurrence of technical errors found while performing the Deashi-harai.

\begin{tabular}{lccc}
\hline & Error & Frequency & Percentage \\
\hline Grip & AGR & 10 & $20 \%$ \\
\hline Off-balance & NOB & 34 & $68 \%$ \\
\hline Right-foot position & IRFP & 21 & $42 \%$ \\
\hline Sweeping action & SWPS & 17 & $34 \%$ \\
\hline \multirow{4}{*}{ Arm action } & SWMC & 28 & $56 \%$ \\
& SWMV & 32 & $64 \%$ \\
& SWTM & 14 & $28 \%$ \\
\hline Throw stage & RAB & 31 & $62 \%$ \\
& LAB & 34 & $68 \%$ \\
\hline Control stage & SWTM & 14 & $28 \%$ \\
& TB & 2 & $4 \%$ \\
& FAC & 14 & $28 \%$ \\
\hline Rebalancing & FNC & 11 & $8 \%$ \\
\hline Globality & KTB & 2 & $22 \%$ \\
\hline & RRF & 12 & $4 \%$ \\
\hline
\end{tabular}

Therefore, at the time of the projection, the Tori's position is not optimal and leads to a less effective action of the arms (RAB-LAB), therefore, the Tori has to rebalance with his left foot (RLF), after running the sweep of the projection.

The relationship between IRFP and RAB-LAB displayed on this T-pattern is relevant because it indicates that a position near to the Tori's body (IRFP) could have a negative influence on the subsequent execution of the action of the arms (RAB -LAB). The coincidence of these four categories (NOB-IRFP-RAB,LAB-RLF) was detected on six occasions, so the relationship between these errors can be considered significant.

Additionally, the dendogram in Figure 2 shows a strong relationship between the lack of a proper grip (AGR) and the inappropriate imbalance (NOB), which produces insufficient traction of the arms (RAB and LAB) when the Tori drives the action at the end of the technique. It has also been confirmed that an improper placement of the right foot (IRFP) in conjunction with those errors (AGR, RAB and LAB) is strongly linked to other technical errors associated with the reaping action (SWPS, SWMC, SWMV SWTM) and with the feet rebalancing action at the end of the Deashi-harai judo-technique (RRF and RLF).
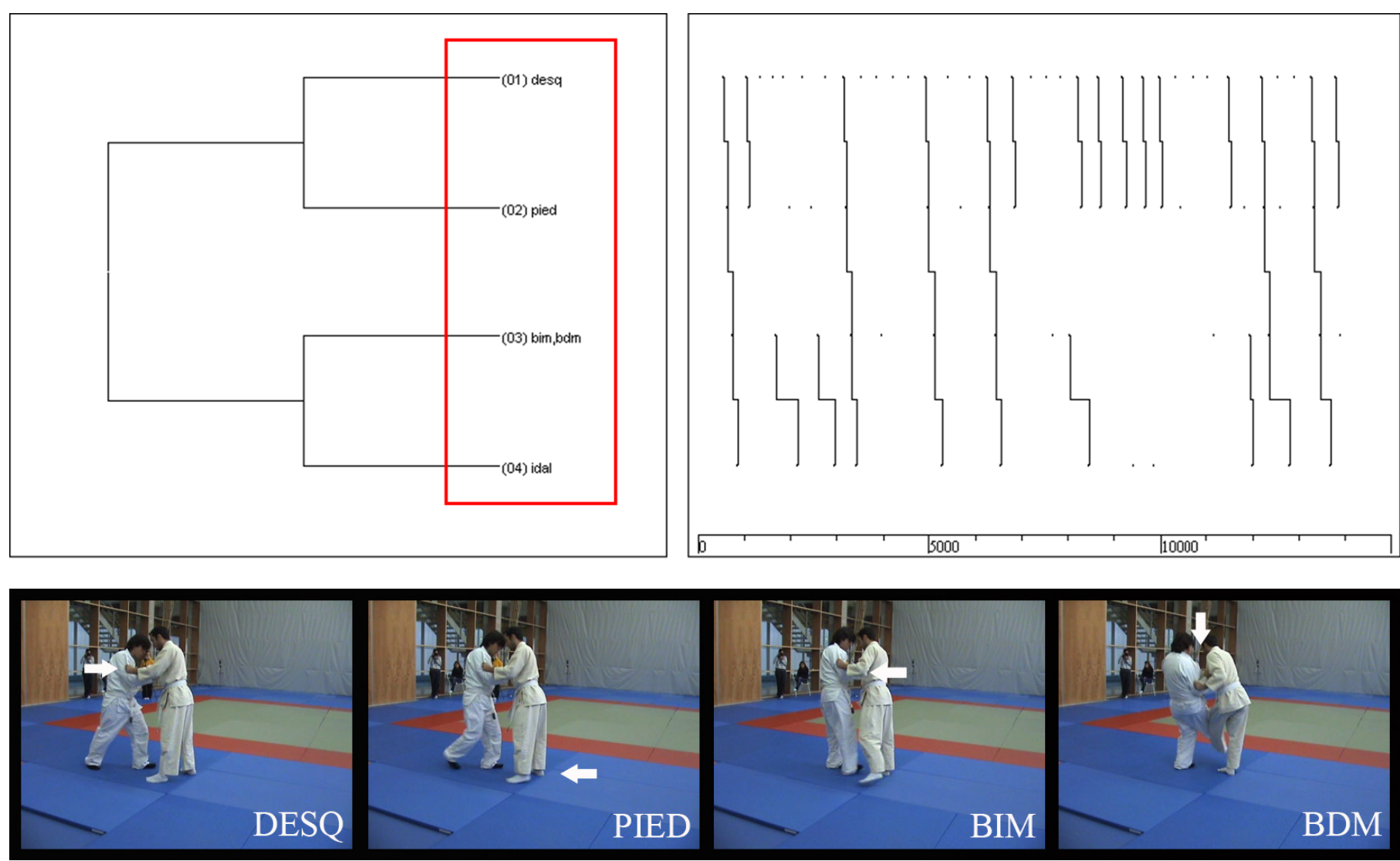

Figure 1. First dendogram of Deashi-harai. 

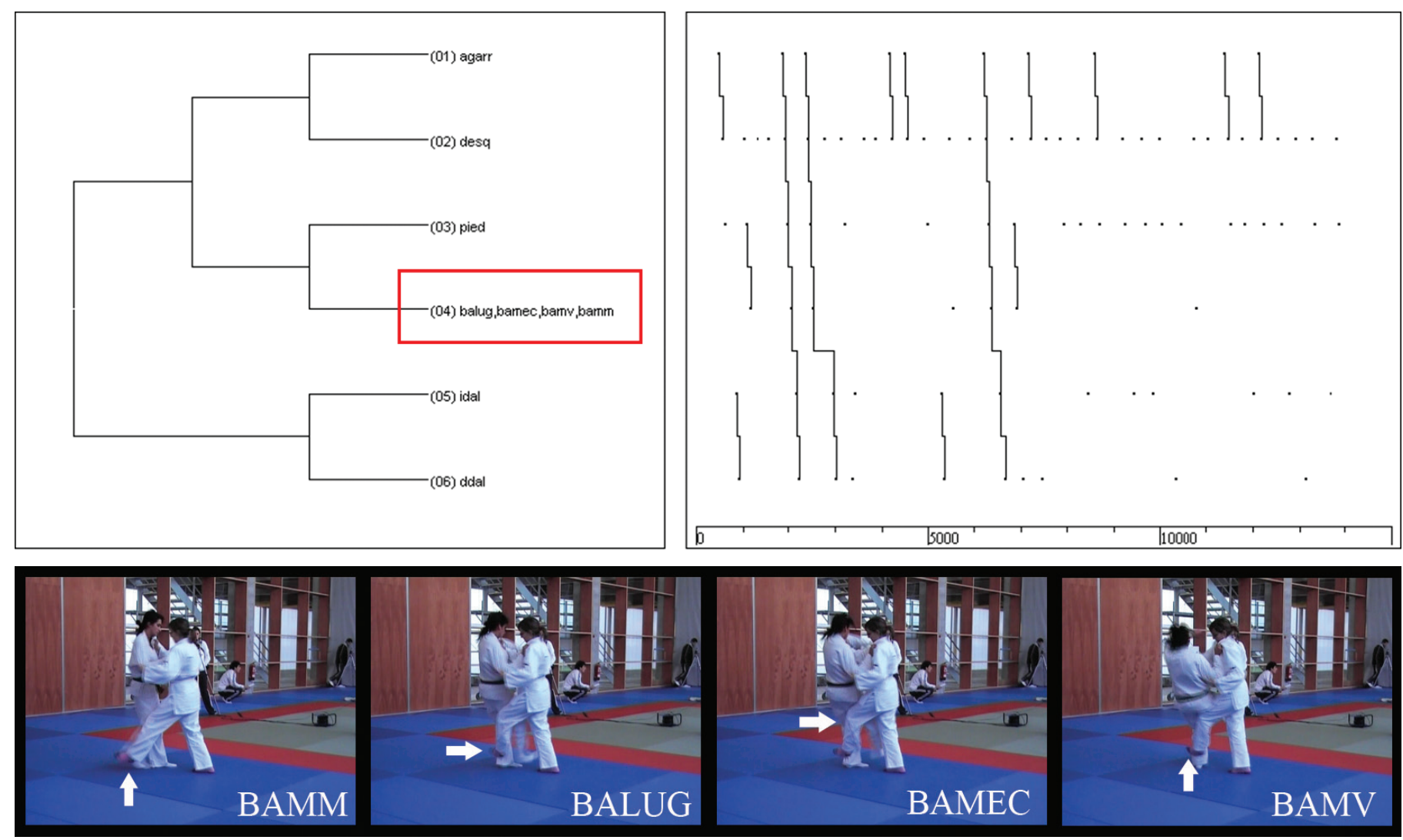

Figure 2. Fifth dendogram of Deashi-harai.

\section{Discussion}

Authors, such as Daigo, 2005; Mifune, 2004 and Ohlenkamp, 2006, have pointed out the key aspects or the most common technical errors when describing a technique. Such indications are based on the personal and professional experience. We agree that experience is one of the most important variables in the teaching-learning process. In fact, our study confirms this aspect. However, we found a number of errors unnoticed by many authors in this sport area. Our approach helps to add scientific data to personal opinions and experiences, and filters the information found in books or manuals relating this sport. In addition, one of the contributions of this research is the detection of sequences of errors during the execution of judo techniques. This aspect, to our knowledge, has not been previously reported in the literature.

In general, the studies highlight the importance of the correct performance of the imbalance action at the initiation of the technique (NOB), specially prior the sweeping action, when the Tori moves the Uke's leg forward by a strong traction with his left arm on the right sleeve of the Uke's judogi (Daigo, 2005; Kudo, 1979; Mifune, 2004).

During the motor action of the Deashi-harai throwing technique, the sweep is the action where most of the errors take place. In this regard, the place where the Tori sweeps the Uke's leg (SWPS) is a topic that has been tackled by several authors (Daigo, 2005; Kano, 1994; Kudo, 1979). These studies indicate that the exact site to initiate the technical motion is the middle part of the ankle and not the heel or another part of the leg (like the shank or thigh). Otherwise, it could completely lose its effectiveness.

In general, the literature refers to the mechanics of sweeping (SWMC), pointing out that, in the course of this movement, the sole of the Tori's foot should be the body-part contact when sweeping the Uke's left ankle, keeping the leg outstretched (Daigo, 2005; Inogai \& Habersetzer, 2002; Mifune, 2004; Ohlenkamp, 2006).

In relation to the sweeping biomechanics (SWMV), the majority of authors (Daigo, 2005; Inogai \& Habersetzer, 2002; Taira, 2009) highlight that it is important that the Tori's sweeping foot keeps close to the ground, directing it from the outside in, sharply and with a round movement at a high speed.

Some authors (Daigo, 2005; Mifune, 2004) agree that the key technical skill lies in the instant (SWTM) when the sweeping action is performed. In fact, everybody indicates that the moment in which the sweeping action must be carried out is just prior to the moment when the foot displaced the Uke's supports of his entire body weight (Daigo, 2005; Inogai \& Habersetzer, 2002).

Moreover, a low energetic pulling action was noticed in almost all participants with their arms is at the final stage of the Deashi-harai throwing technique (RAB and LAB). The methodological recommendations (Daigo, 2005; Kano, 1994) clearly indicate the importance of the pulling action with the arms, which must be performed at the same time of the sweep action with a vigorous jolt.

The sequential errors described above (Figures 1 and 2) are not specifically mentioned by most authors, who usually focus 
their attention on the important aspects or the characteristic description of the Deashi-harai technique. Regarding the link between the common error IRFP and the sweeping action errors (SWPS, SWMC, SWMV, SWTM) Taira (2009) stated the following (p. 217): “... the Tai-Sabaki (displacement of the body) must be carried out with a great skill, and the foot that loads the body weight has to be in the place that allows to carry out the sweeping action while preserving the balance...".

Nonetheless, Mifune (2004) identified the importance of correctly unbalancing the Uke's body (NOB) in order to continue the technical sweep action appropriately, highlighting the noticeable relation between the NOB and the sweeping errors (SWPS, SWMC, SWMV, SWTM). Kolychkine (1989) specifies it by writing the following statement (p. 63): "The Tori must coordinate the imbalance action with the sweeping action, in order to attract the Uke's body...". Daigo (2005) also described the importance of the unstable position of the Uke in order to achieve the most favorable conditions for the driving action.

Finally, regarding the relationship between the lack of action of the Tori's arms at the final stage of the Deashi-harai technique (RAB and LAB) and the deficient sweeping action (SWPS, SWMC, SWMV, SWTM), Franco (1985) pointed out that the simultaneous and synchronized performance of those actions is crucial, suggesting that an inefficient performance of the first one would have a significant impact on the performance of the last one.

\section{Conclusions}

The most frequent errors detected in Deashi-harai were: 1. lack of initial imbalance; 2 . improper placement of the right foot in front of the opponent's right foot during Tsukuri; 3. and lack of the arms action in the final phase of the projection.

The most relevant error sequences found were: 1 . absence of imbalance reduces the likelihood of the foot and the body to be placed in a correct position, and 2. the placement of the right foot in front of the Uke's right foot makes it difficult to develop a proper movement of the arms and a correct sweep action.

\section{Practical implications}

The results of this study enable to propose a number of strategies based on the knowledge of the performance with the aim of improving the teaching and learning of the Deashi-harai technique:

When demonstrating the technique, the student's attention should be directed towards the key points highlighted in this study. As for the theoretical aspects of throw, we believe that coaches could find useful to incorporate some video-recordings or other images illustrating the fundamental features and the common errors detected in a sport performance. In any case, teachers or coaches should only focus on the most relevant aspects. Instructors could design tasks or drills that draw the student's attention to the most significant errors and sequences of the detected behavior.

After a throw execution in a training session, the subsequent communication between coaches and students could be improved by providing a more precise feedback. Coaches should firstly consider the most significant errors and sequences identified in the present study, leaving others for a later stage of training. It also would be helpful to take into consideration just a few key aspects to avoid overloading the students with an excess of information. At all events, the results of this study can provide a platform for different kinds of feedback (verbal, verbal with a practical demonstration or verbal with hands-on assistance), which should always be positive in nature.

Coaches could create some observation/evaluation sheets based on the category system of the observation instrument used in this study. One model would be for the students to work in groups of three, with one of them observing the two other while they are performing the throw. This student would, therefore, conduct an observational analysis using the evaluation sheet, noting the errors made and providing an immediate feedback. The same observational analysis could also be carried out after the performance of the throw by means of video recordings.

\section{References}

Anguera, M. T., Blanco-Villaseñor, A., \& Losada, J. L. (2001). Diseños Observacionales, cuestión clave en el proceso de la metodología observacional [Observational designs, a key aspect in the process of observational methodology]. Metodología de las Ciencias del Comportamiento, 3, 135-61.

Anguera, M. T., \& Jonsson, G. K. (2003). Detection of real-time patterns in sport: Interactions in football. International Journal of Computer Science in Sport, 2(2), 118-21.

Bakeman, R., \& Quera, V. (1992). SDIS. A sequential data interchange standard. Behavior Research Methods Instruments \& Computers, 24, 554-9. doi:10.3758/BF03203604

Bakeman, R., \& Quera, V. (2001). Using GSEQ with SPSS. Metodología de las Ciencias del Comportamiento, 3, 195-214.

Bakeman, R., \& Quera, V. (2011). Sequential Analysis and Observational Methods for the Behavioral Sciences. Cambridge: Cambridge University Press.

Bandura, A. (1977). Self-efficacy: toward a unifying theory of behavioral change. Psychological Review, 84, 191-215. doi:10.1037// 0033-295X.84.2.191

Borrie, A., Jonsson, G. K., \& Magnusson, M. S. (2002). Temporal pattern analysis and its applicability in sport: An explanation and exemplar data. Journal of Sports Sciences, 20, 845-52. doi: 10.1080/026404102320675675

Camerino, O., Chaverri, J., Anguera, M. T., \& Jonsson, G. K. (2012). Dynamics of the game in soccer: Detection of T-patterns. European Journal of Sport Science, 12(3), 216-224.

Castellano, J., Perea, A., Alday, L., \& Mendo, A. H. (2008). The Measuring and Observation Tool in Sports. Behavior Research Methods, 40, 898-905. doi: 10.3758/BRM.40.3.898

Cohen, J. (1968). Weighed kappa: Nominal scale agreement with provision for scaled disagreement or partial credit. Psychological Bulletin, 70, 213-220.

Daigo, T. (2005). Kodokan Judo Throwing Techniques. Tokyo: Kodansha Internacional.

Fernández, J., Camerino, O., Anguera, M. T., \& Jonsson, G. K. (2009). Identifying and analyzing the construction and effectiveness of offensive plays in basketball by using systematic observation. Behavior Research Methods, 41, 719-30. doi:10.3758/BRM.41.3.719

Franco, F. (1985). Cinturón negro de judo [Judo black belt]. Madrid: Esteban Sanz Martínez. 
García, J. M., Carratalá, V., Sterkowicz, S., \& Escobar, R. (2009). A study of the difficulties involved in introducing young children to judo techniques: A proposed teaching programme. Archives of Budo, 5, 121-126.

Gentile, A. M. (1972). A working model of skill acquisition with application to teaching. Quest, 17, 3-23. doi:10.1080/00336297 .1972 .10519717

Gutiérrez-Santiago, A., Cancela, J. M., Zubiaur, M., \& Ayán, C. (2012). Are Male Judokas with Visual Impairments Training Properly? Findings from an Observational Study. Journal of Visual Impairment \& Blindness, 106(4), 224-234.

Gutiérrez-Santiago, A., Prieto, I., Ayán, C., \& Cancela, J. M. (2013). T-Pattern Detection in Judo Combat: An Approach to Training Male Judokas with Visual Impairments According to their Weight Category. International Journal of Sports Science \& Coaching, 8(2), 384-394.

Gutiérrez-Santiago, A., Prieto, I., Camerino, O., \& Anguera, M. T. (2011). The temporal structure of judo bouts in visually impaired men and women. Journal of Sports Sciences, 29, 1443-1451. doi: 10.1080/02640414.2011.603156

Hodges, N. J., \& Franks, I. M. (2002). Modelling coaching practice: the role of instruction and demonstration. Journal of Sports Sciences, 20, 793-811. doi: 10.1080/026404102320675648

Inogai, T., \& Habersetzer, R. (2002). Judo pratique. Du débutant à la ceinture noire [Judo practice. From the beginner to the black belt $]$. París: Amphora.

Kano, J. (1994). Kodokan Judo. Tokyo: Kodansha Internacional.

Kodokan (n.d). Nage Waza: various techniques and their names [Video]. Tokyo: Kodokan Judo Video Series.

Kolychkine, A. (1989). Judo. Nueva didáctica [Judo: New teaching methods]. Barcelona: Paidotribo.

Kudo, K. (1979). Judo en acción [Judo in action]. Bilbao: Fher.

Magnusson, M.S. (1996). Hidden real-time patterns in intra- and inter-individual behavior. European Journal of Psychological Assessment, 12(2), 112-123.

Magnusson, M. S. (2000). Discovering hidden time patterns in behavior: T-patterns and their detection. Behavior Research Methods Instruments \& Computers, 32, 93-110. doi:10.3758/BF03200792

Magnusson, M. S. (2005). Understanding social interaction: discovering hidden structure with models and algorithms. In L. Anolli, S. Duncan, M. S. Magnusson. \& G. Riva (Eds.), The hidden structure of social interaction. From Genomics to Culture Patterns (pp.2-21). Ámsterdam, The Netherlands: IOS Press.

McCullagh, P. (1986). A model status as a determinant of attention in observational learning and performance. Journal of Sport \& Exercise Psychology, 8, 319-331.

Mifune, K. (2004). The canon of Judo: classic teachings on principles and techniques. Tokyo: Kodansha International.

Newell, K. M., \& Walter, C. B. (1981). Kinematic and kinetic parameters as information feedback in motor skill acquisition. Journal of Human Movement Studies, 7, 235-54.

Ohlenkamp, N. (2006). Black Belt. Judo Skills and Techniques. London: New Holland Publishers (UK).

Pereira, F., Mesquita, I., Graça, A., \& Moreno, M. P. (2010). Análisis multidimensional del feedback pedagógico en entrenamiento en voleibol [Multidimensional analysis of pedagogical feedback in volleyball training setting]. International Journal of Medicine and Science of Physical Activity and Sport, 10, 181-202. Http:// cdeporte.rediris.es/revista/revista38/artanalisis146.htm

Reo, J. A., \& Mercer, V. S. (2004). Effects of live, videotaped, or written instruction on learning an upper-extremity exercise program. Physical Therapy, 84, 622-633. http://ptjournal.apta.org/ content $/ 84 / 7 / 622$
Taira, S. (2009). La esencia del judo I [The essence of judo I]. Gijón: Satori Ediciones.

Tzetzis, G., Votsis, E., \& Kourtessis, T. (2008). The effect of different corrective feedback methods on the outcome and selfconfidence of young athletes. Journal of Sports Science and Medicine, 7, 371378. http://www.jssm.org/vol7/n3/9/v7n3-9text.php

Wilcoxon, F. (1945). Individual comparisons by ranking methods. Biometrics Bulletin, 1, 80-83. doi:10.2307/3001968

Zabala, M., Sánchez-Muñoz, C., Mateo, M. (2009). Effects of the administration of feedback on performance of the BMX cycling gate start. Journal of Sports Science and Medicine, 8, 393-400. http://www.jssm.org/vol8/n3/12/v8n3-12text.php

Zubiaur, M. (1998). El conocimiento de la ejecución [Knowledge of performance]. Motricidad. European Journal of Human Movement, 4, 97-111. http://bit.ly/Rd1bqF

Zubiaur, M. (2005). Algunas consideraciones sobre la utilización del modelado en la adquisición de habilidades motrices en niños [Some considerations on the use of modelling in the acquisition of motor skills in children]. Revista de Psicologia del Deporte, 14, 85-97. http://www.rpd-online.com/article/view/193/193

\section{Authors' note}

Dr. Alfonso Gutiérrez Santiago:

Faculty of Education and Sports Sciences, University of Vigo, Spain. Address: Facultad de Ciencias de la Educación y del Deporte. Campus A Xunqueira s/n 36005 Pontevedra (Spain).

Phone: +34 986801700

e-mail: ags@uvigo.es

Dr. Iván Prieto Lage is with the Faculty of Education and Sports Sciences, University of Vigo, Spain.

Address: Facultad de Ciencias de la Educación y del Deporte. Campus A Xunqueira s/n 36005 Pontevedra (Spain).

Phone: +34 654912427

e-mail: ivanprieto@uvigo.es

Dr. Miguel Ángel Prieto Lage

Instituto de Investigaciones Marinas (IIM-CSIC)

Address: Instituto de Investigaciones Marinas (IIM-CSIC). C/ Eduardo

Cabello n ${ }^{\circ} 636208$ Vigo, Pontevedra (Spain).

Phone: +34 654694616

E-mail: michaelumangelum@gmail.com

\section{Corresponding author:}

Ivan Prieto Lage

Faculty of Education and Sports Sciences, University of Vigo, Spain. e-mail: ivanprieto@uvigo.es

Phone: +34 654912427

Manuscript received on October 23, 2012

Manuscript accepted on January 15, 2014

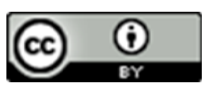

